\title{
Evolution of antibody response and fungal antigens in the serum of a patient infected with Candida famata
}

\author{
Diana Pisa, Marta Ramos, Susana Molina, Patricia García \\ and Luis Carrasco
}

Correspondence

Luis Carrasco

Icarrasco@cbm.uam.es

Received 31 October 2006

Accepted 25 January 2007

\author{
Centro de Biología Molecular (CSIC-UAM), Facultad de Ciencias, Universidad Autónoma, \\ Cantoblanco, 28049 Madrid, Spain
}

\begin{abstract}
The presence of fungal antibodies and antigens in the serum of a patient diagnosed in 1996 with acute zonal occult outer retinopathy caused by Candida famata infection was examined. Antibodies against C. famata increased until 1999-2000 when antifungal treatment was initiated. The antibodies were detected by ELISA and immunofluorescence analysis using C. famata. These antibodies were not immunoreactive against several Candida species tested. Positive immunofluorescence was obtained with $\lg M$, but not $\lg A, \lg G$ or $\lg E$. Moreover, the $\lg M$ response disappeared several months after treatment with antifungal compounds, despite the fact that $C$. famata antigens were present in the blood. Finally, a sensitive test was developed to assay for the presence of $C$. famata antigens in serum based on the immunodetection of fungal antigens transferred to a nitrocellulose membrane and incubated with rabbit antibodies raised against $C$. famata. According to this method, the infection diminished with antifungal treatment.
\end{abstract}

\section{INTRODUCTION}

The immunological response to fungal infections in humans is complex and still subject to much debate (Coleman et al., 1998; d'Ostiani et al., 2000; Gil, 1997; Lopez-Ribot et al., 2004; Mencacci et al., 1999; Pfaller, 1996; Shoham \& Levitz, 2005). Cellular response, particularly macrophage function, may be crucial in combating systemic infections produced by different fungi (Badauy et al., 2005; d'Ostiani et al., 2000; Simitsopoulou \& Roilides, 2005; Villar et al., 2005). However, the importance of a robust antibody response to Candida infections has also been documented (Fernandez-Arenas et al., 2004; Mencacci et al., 1999; Witkin et al., 1983). The fact that systemic candidiasis is much more common in immunocompromised patients points to a key role for the immune system in preventing this infection (Altamura et al., 2001; Clemons et al., 2000; Ruhnke, 2006; Sims et al., 2005). Cellular immune response, together with the humoral response and innate immunity, are most likely necessary for efficient control of this type of systemic infection (Altamura et al., 2001; Lopez-Ribot et al., 2004). Although many studies have described the immune response in human candidiasis (Lopez-Ribot et al., 2004; Mencacci et al., 1999; Rozell et al., 2006), hardly any have attempted to characterize the antibodies of patients infected with Candida famata.
Candida spp. account for a large percentage of human fungal infections. Apart from Candida albicans, which represents about $50 \%$ of blood isolates (Canteros et al., 1994; Peres-Bota et al., 2004), other species such as Candida glabrata, Candida parapsilosis, Candida tropicalis and Candida krusei have been found in the blood of infected patients (Al-Hedaithy, 2003; Almirante et al., 2006; Brandt et al., 2000; Fanci et al., 2005; Veldman et al., 2006; Wagner et al., 2005; Yang et al., 2003). Viable $C$. famata has been found in about $1-2 \%$ of patients suffering from systemic candidiasis (Al-Hedaithy, 2003; Canteros et al., 1994; Krcmery \& Barnes, 2002; Peres-Bota et al., 2004; Pfaller et al., 2003; Prinsloo et al., 2003; Ruhnke, 2006; Tortorano et al., 2006; Yamamoto et al., 2002), but analysis of the presence of genomes by PCR yields a different percentage (Khan \& Mustafa, 2001; Pryce et al., 2003; van Deventer et al., 1995). Although C. famata is considered to be non-pathogenic (Andrighetto et al., 2000; Gardini et al., 2001), it has been found in tissues as diverse as bone, blood and the CNS, and is associated with vision problems (Krcmery \& Kunova, 2000; Prinsloo et al., 2003; Rao et al., 1991; St-Germain \& Laverdiere, 1986). Recent evidence suggests that $C$. famata is the aetiological agent responsible for acute zonal occult outer retinopathy (AZOOR). We report here in detail the antibody response in an AZOOR patient described previously (Carrasco et al., 2005). We also monitored the course of infection using different methods. Correct diagnosis of disseminated candidiasis is still elusive in some patients; thus different approaches are needed to demonstrate disseminated fungal 
infection (Ellepola \& Morrison, 2005; Pontón, 2006; Yeo \& Wong, 2002). In most hospitals, haemocultures are the main routine assay for detecting disseminated candidiasis (Ellepola \& Morrison, 2005). However, unlike systemic candidiasis, viable Candida cells are seldom present in disseminated infections. PCR can overcome this problem but at least one fungal genome per assay must be present to determine the presence of yeast cells in blood (Bretagne \& Costa, 2005). Other methods are based on detecting fungal metabolites or other components, such as proteins or polysaccharides, in blood serum (Ishibashi et al., 2005; Mitsutake et al., 1996; Pontón, 2006). Some of these methods detect specific proteins, such as glycolytic enzymes, heat-shock proteins or secreted proteases. The use of immunological assays to determine the presence of these proteins in human blood serum constitutes a more sensitive test for diagnosis of disseminated candidiasis. Diverse commercial kits have been developed to assay the presence of polysaccharides such as mannans or glucans in serum. We compared these techniques in serum samples taken at different times from a patient infected with $C$. famata. Our results suggest that analysis of fungal proteins in serum constitutes the most sensitive test to monitor the course of this infection.

\section{METHODS}

Yeast growth. The yeast was grown in YEPD medium $(1 \%$ yeast extract, $2 \%$ peptone, $2 \%$ glucose) by incubation at $30{ }^{\circ} \mathrm{C}$. The same medium, containing agar, was used to isolate individual yeast colonies.

Antibodies. Rabbit antisera against different yeast species were obtained by inoculation of $0.5 \mathrm{ml}$ phosphate-buffered saline (PBS) containing 1 or $2 \mathrm{mg}$ yeast after autoclaving and lyophilization. Each inoculum had been mixed previously with the same volume of Freund's adjuvant. Rabbits were inoculated up to four times and the antibody titre and specificity of the sera were tested by immunofluorescence and Western blotting.

Immunofluorescence and immunoelectron microscopy. For $C$. famata, $1 \mathrm{ml}$ culture was placed in $1.5 \mathrm{ml}$ microcentrifuge tubes. Cells were washed with PBS, incubated with $50 \mathrm{mM}$ ammonium chloride for $10 \mathrm{~min}$ and washed three times with PBS/Tween 20. Cells were then treated with the different sera diluted $1: 500$ in PBS/Tween 20 at $37{ }^{\circ} \mathrm{C}$ for $2 \mathrm{~h}$, washed again with PBS/Tween 20 and incubated with the secondary antibody. Goat anti-human IgA, IgM and IgG (Sigma), or rabbit anti-IgG + IgA + IgM (Abcam), conjugated to fluorescein antibodies, were added at a $1: 500$ dilution; in some cases anti-IgG4 and IgE antibodies were used (a generous gift from M. Lombardero, ALK, Abelló, Madrid, Spain). In these cases, samples were then incubated with an anti-Ig fluorescein-conjugated antibody. The samples were incubated at $37{ }^{\circ} \mathrm{C}$ for another hour. The cells were then washed, resuspended in PBS and mounted on slides with a drop of Depex (Serva). Finally, the cells were observed under a fluorescence microscope. For the remaining Candida species, a Euroimmun kit (Medizinische Labordiagnostika) was used in accordance with the manufacturer's instructions and using the same serum dilutions as for C. famata. For immunoelectron microscopy, we followed a protocol described elsewhere (Wright et al., 1988), with some modifications: the cells were fixed for $2 \mathrm{~h}$ at room temperature in $2 \%$ glutaraldehyde in $0.1 \mathrm{M}$ cacodylate buffer ( $\mathrm{pH} 7.2$ ) and washed after post-fixation with $0.15 \%$ tannic acid in $0.05 \mathrm{M}$ cacodylate buffer ( $\mathrm{pH}$ 7.2). Cells were finally embedded in Epon (TAAB Laboratories). The sections were rehydrated in PBS and immersed in $0.5 \mathrm{M} \mathrm{NH}_{2} \mathrm{Cl}$ for $15 \mathrm{~min}$. Samples were then blocked with $1 \%$ BSA in PBS, incubated for $1 \mathrm{~h}$ with the primary antibody diluted in $1 \%$ low-fat dried milk in PBS at room temperature and subsequently washed with $0.1 \%$ BSA in PBS. After washing, secondary antibody conjugated to colloidal gold particles was added at a 1:10 000 dilution in PBS. Finally, samples were washed again with PBS and once again with triple-distilled water. The samples were analysed with a JEOL 1010 electron microscope.

ELISA. ELISA was carried out as described previously (Carrasco et al., 2005). Briefly, a C. famata cell suspension diluted in PBS was seeded in ELISA microtitre plates (Maxisorp; Nunc). The plates were blocked with PBS containing 3\% low-fat dried milk and $0.2 \%$ Tween 20 . Serum from the AZOOR patient was added at a $1: 200$ dilution and plates were subsequently incubated with goat anti-human (heavy and light chain) Ig horseradish peroxidase-conjugated antibodies (Pierce) and washed five times. Colour development was accomplished by incubation with $o$-phenylenediamine (Sigma) and measured at $490 \mathrm{~nm}$ in a microplate reader (EL340; Bio-Tek Instruments).

Western blot assays. Yeast proteins were precipitated with trichloroacetic acid (10\%) and fractionated by SDS-PAGE with $15 \%$ polyacrylamide, transferred to nitrocellulose membranes by wet immunotransfer and processed for Western blotting. Blocking, incubation with antibodies and washing were performed as described above for ELISA. Goat anti-human IgM horseradish peroxidaseconjugated antibodies (Amersham Biosciences) and an ECL kit (Amersham) were used to detect bound antibodies. Chemiluminescence was detected by exposure to Agfa X-ray film.

PCR analyses. DNA was extracted from serum or whole blood. To this end, $200 \mu \mathrm{l}$ serum was boiled for $10 \mathrm{~min}$ and then incubated for $2 \mathrm{~h}$ at $37^{\circ} \mathrm{C}$ with Zimolase (ICN) and for a further $2 \mathrm{~h}$ at $58{ }^{\circ} \mathrm{C}$ with proteinase K (Sigma). A detergent buffer $(200 \mu \mathrm{l})$ was added and samples were boiled again for $10 \mathrm{~min}$ before adding $1 \mathrm{ml}$ phenol/ chloroform (1:1; Amersham) and centrifuging at $20000 \mathrm{~g}$ for $20 \mathrm{~min}$. The upper aqueous phase was recovered and washed twice with ethyl ether. The DNA was precipitated by the addition of 3 vols absolute ethanol $\left(-20{ }^{\circ} \mathrm{C}\right.$; Merck) to the aqueous phase. After storing the samples overnight at $-20{ }^{\circ} \mathrm{C}$, the DNA was centrifuged at $20000 \mathrm{~g}$ for 20 min. Pellets were dried and resuspended in $\mathrm{H}_{2} \mathrm{O}$. The DNA preparations were incubated with oligonucleotides that hybridize to the rRNA genes (Li et al., 2003; Nishikawa et al., 1999) and amplify the first internal transcribed spacer region. The amplified product was analysed by agarose gel electrophoresis. The corresponding band was sequenced to determine unequivocally the presence of C. famata genomes. Real-time quantitative PCR was carried out in an ABI PRISM 7000 thermocycler (Applied Biosystems). The reaction mix was prepared with each oligonucleotide at $0.9 \mu \mathrm{M}$ and $0.25 \mu \mathrm{M}$ TaqMan probe in a final volume of $20 \mu$, to which 50 ng DNA was added. The concentration of DNA template was normalized against previous PCRs with specific oligonucleotides in which DNA was denatured at $95{ }^{\circ} \mathrm{C}$ for $10 \mathrm{~min}$ and amplified using 40 cycles of $15 \mathrm{~s}$ at $95{ }^{\circ} \mathrm{C}$ and $1 \mathrm{~min}$ at $60{ }^{\circ} \mathrm{C}$. Analysis of the data was carried out using SDS 7000 (v1.1) software.

Dot-blot analyses. Different serum dilutions $(200 \mu \mathrm{l})$ in TBS were added to each well. Samples were blotted onto a $45 \mathrm{~mm}$ nitrocellulose membrane (Bio-Rad) previously hydrated in TBS for 10 min using a Bio-Dot SF apparatus (Bio-Rad). After blotting, the membrane was processed and developed as described above for Western blotting. The primary antibodies, rabbit polyclonal antibodies raised against C. famata, C. albicans, C. glabrata, C. parapsilopsis, Rhodotorula mucilaginosa or Saccharomyces cerevisiae, were used at a $1: 1000$ 
dilution. A donkey anti-rabbit IgG horseradish peroxidase-conjugated antibody (Amersham Biosciences) at a 1:5000 dilution was used as secondary antibody.

Detection of fungal polysaccharides. The presence of mannoses and $\beta-1,3$ glucan in serum was detected using the Platelia Candida AG test (Bio-Rad), as described by the manufacturer, or the Fungitell serum assay kit, performed by Fontlab (Barcelona, Spain) (Pazos et al., 2005).

\section{RESULTS AND DISCUSSION}

The characteristics of our patient have been described previously (Carrasco et al., 2005). Briefly, the patient was diagnosed with AZOOR in 1996 (aged 47). In 1999, C. famata was isolated from conjunctival exudate and blood. At the end of this year, intermittent antifungal treatment was administered as described previously (Carrasco et al., 2005). Initially, the presence of anti- $C$. famata antibodies from serum obtained from different years was analysed by ELISA (Fig. 1a). The C. famata antibody titre increased until 1999. After administration of antifungal compounds, a clear decrease in the antibody titre was observed and it has remained low ever since. Analysis of these antibodies by immunofluorescence using C. famata also corroborated this observation (Fig. 1b). Thus positive immunofluorescence appeared with the sera obtained in June 1999, September 1999 and January 2000. Low reactivity was found with sera from June 1996 and August 2001, while no antibodies were detected from serum obtained in October 2005. The immunofluorescence observed with other yeast species was similar to that of the negative control without primary antibody. Only a slight reaction with C. tropicalis appeared, suggesting that the antibodies were fairly specific to C. famata in the immunofluorescence test. In our experience, some human sera do react with $C$. tropicalis in the Euroimmun test. Therefore, we consider this reactivity to be non-specific. Next, we wanted to analyse the type of antibody present in the positive serum from 1999. For this, a second anti-human antibody specific for IgA, IgM, IgG, IgG4 or IgE was employed after incubation of C. famata with this serum (Fig. 2). Interestingly, this assay revealed the presence of IgM but not IgG antibodies, even though the patient had been infected over several years. On the other hand, these IgM antibodies were not cross-reactive with C. albicans (Fig. 2). This serum was also analysed by Western blotting against C. famata proteins. Fig. 3(a) shows that there were two yeast proteins that gave a stronger reaction with serum from September 1999. These two proteins, of about 41 and $30 \mathrm{kDa}$, reacted more weakly with sera from October 2005, January 2006 and the control healthy donor. In addition, there were other proteins that immunoreacted non-specifically with all of the sera employed, such as a $47 \mathrm{kDa}$ protein. Western blotting using C. albicans proteins revealed a low reactivity with the patient's serum, compared with a serum from a control patient infected with C. albicans. Moreover, no immunoreactivity was found against proteins from Cryptococcus magnus (Fig. 3a). Immunogold electron microscopy
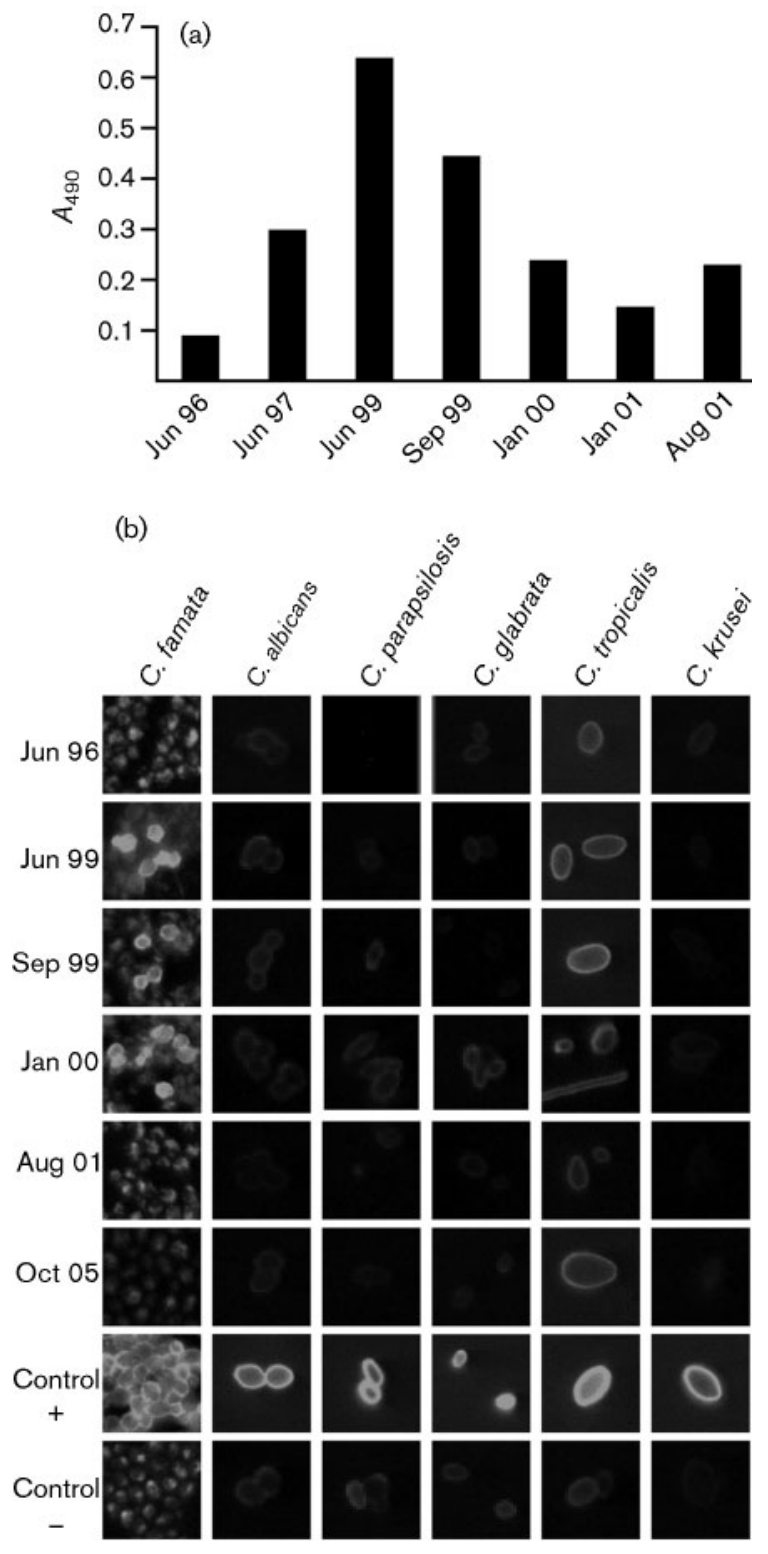

Fig. 1. (a) ELISA to determine the presence of antibodies against C. famata in patient sera from different years. The assay was carried out as described in Methods. (b) Immunofluorescence analysis of different yeasts using different patient sera. In the case of C. famata, the protocol described in Methods was followed. As a positive control, rabbit antiserum against $C$. famata was employed; for the negative control, PBS instead of primary antibody was added. The Euroimmun kit for immunofluorescence was used for the remaining yeast species analysed. The controls were those provided by the kit.

analysis was carried out (Fig. 3b). This human antiserum clearly reacted with antigens at or in close proximity to the plasma membrane of C. famata. For comparison, a rabbit antiserum raised against this yeast was employed. It was noteworthy that both human and rabbit antisera recognized a similar structure close to the plasma membrane. 


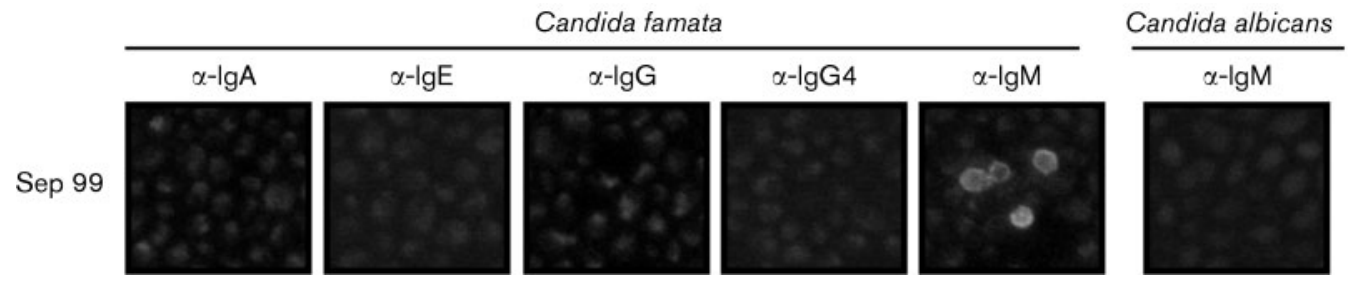

Fig. 2. Analysis of antibody type by immunofluorescence using serum from 1999. C. famata cells were treated as described in Methods and incubated with patient serum from June 1999. A range of anti-human antibodies specific for different immunoglobulins were employed as secondary antibody. As a negative control, PBS was added instead of primary antibody (not shown).

(a)

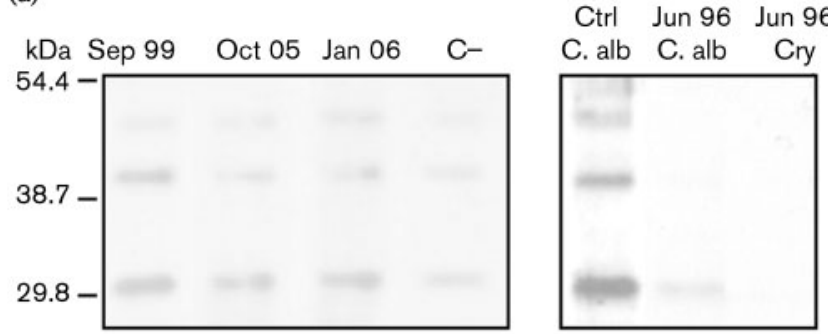

(b)

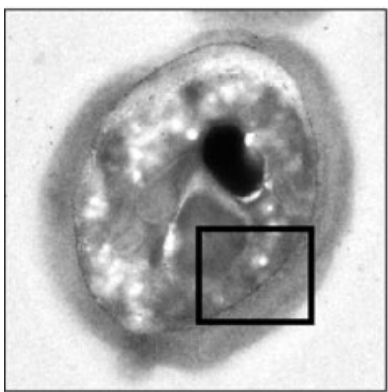

D21 225

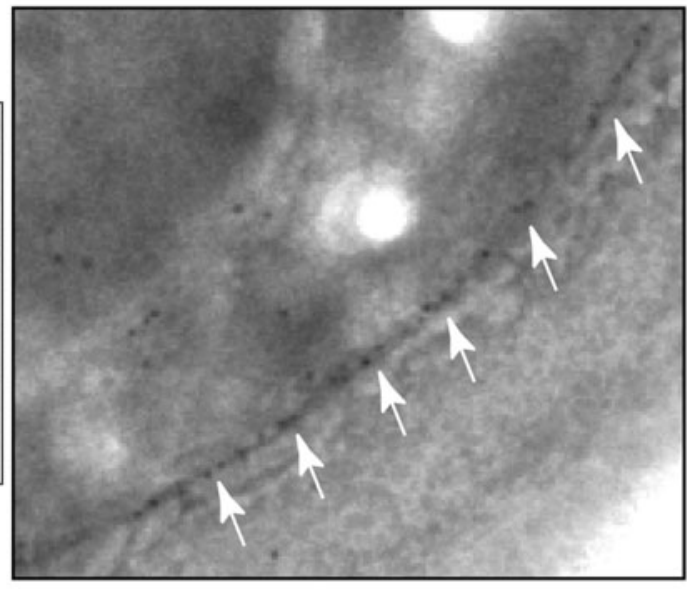

D21 $\times 60$

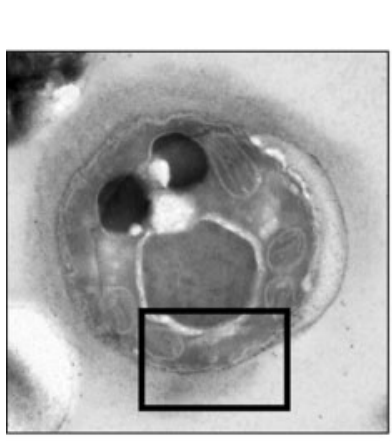

LC $1: \times 25$

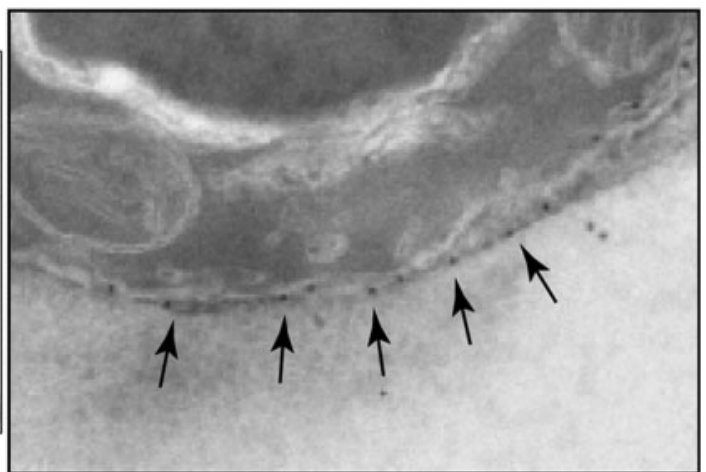

LC 1:200 ×60
Fig. 3. (a) Left panel: Western blot of $C$. famata proteins with different sera from the patient or from a healthy donor (C-). Right panel: Western blot of C. albicans (C. alb) and Cryptococcus magnus (Cry) proteins incubated with the serum obtained from the patient in 1996. Ctrl C. alb, positive control of C. albicans proteins incubated with serum from a patient infected with this yeast. In all cases, the secondary antibody recognized IgM. Serum dilutions were at $1: 4000$, whereas the secondary antibody was used at 1:10000 dilution. (b) Immunoelectron microscopy of $C$. famata cells. Yeast cells were incubated with patient serum (LC 1) or, as a control, with rabbit serum obtained against $C$. famata (D21), and then incubated with secondary antibody conjugated with colloidal gold. Magnifications are indicated. 
As the patient's vision symptoms are not yet fully resolved, we tried to detect the presence of $C$. famata infection using PCR. DNA was extracted from serum and submitted to PCR using oligonucleotides that amplify the first intervening sequence between the rRNA genes, as described above. Real-time quantitative PCR using TaqMan probes was carried out with different samples (Fig. 4a). Evidence for the presence of $C$. famata genomes in the blood sera of this patient was found in the samples from October 1996 and June 1997, despite the fact that no viable yeast cells were recovered from these haemocultures. Furthermore, the presence of fungal genomes clearly diminished from June 1999 , even though some symptoms of infection remained in this patient, such as the appearance of C. famata genomes in conjunctival exudates. The decrease in fungal genomes in blood from October 1996 probably corresponded to the discontinuation of immunosuppression therapy from the end of that year. These findings indicated that the presence of C. famata can be determined by PCR in samples that contain few antibodies and, conversely, that
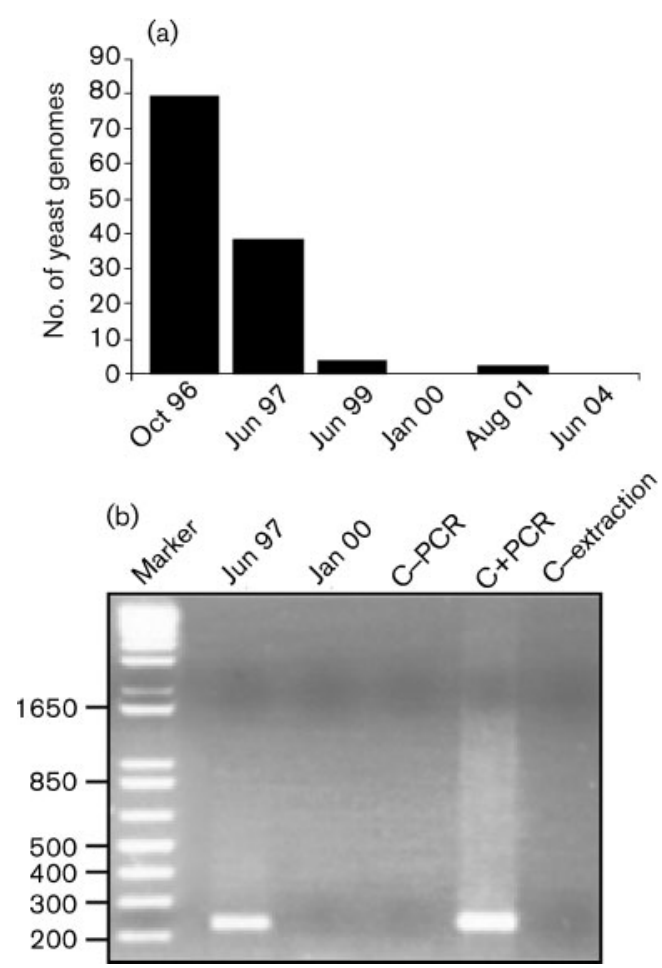

Fig. 4. Detection of C. famata genomes by PCR. (a) Determination of the number of $C$. famata genomes in $200 \mu \mathrm{l}$ serum by quantitative PCR, carried out as described in Methods. (b) PCR analysis of different serum samples obtained from the patient on the dates indicated above each lane. PCR assays were carried out with oligonucleotides that amplify a region of the rRNA gene internal transcribed spacer. C-PCR, negative PCR control without DNA; C+PCR, positive control of DNA extracted from C. famata; $\mathrm{C}$-extraction, negative control of DNA extraction, prepared with phosphate buffer instead of a DNA sample. DNA size markers (bp) are indicated. no fungal genomes are found at the peak of the antibody response. To confirm that the fungal genomes amplified in Fig. 4(a) were from C. famata, the amplified product obtained from another PCR was separated by agarose gel electrophoresis (Fig. 4b). A single product of about $240 \mathrm{nt}$ was apparent in the serum from June 1997, which corresponded to the band obtained from C. famata DNA. This band was extracted and sequenced, revealing that it was indeed C. famata. Although no fungal genomes were detected by PCR from January 2000, abundant C. famata genomes were determined in a number of conjunctival exudates obtained up until May 2006 (data not shown).

As no $C$. famata genomes were detected in sera from recent years, we aimed to develop a system to detect the presence of fungal antigens in the blood serum. Our attempts to find fungal proteins by Western blotting using a rabbit antiserum raised against C. famata were unsuccessful. A much more sensitive test was the detection of proteins using a dot-blot assay. In this test, different serum dilutions were transferred to a nitrocellulose membrane and incubated with rabbit anti-C. famata antibodies. Using this assay, the presence of $C$. famata antigens was evident (Fig. 5a) and decreased over the years (Fig. 5b). This test has the advantage that it can be quantified by densitometry. Thus, with a $1: 500$ dilution, there was no immunoreactivity with sera from healthy donors (Fig. 5a). On the other hand, the patient serum did not react with rabbit pre-immune serum. Notably, some serum samples from the patient gave high test values, particularly before antifungal treatment was initiated. Despite prolonged administration of antifungal compounds, there was still evidence of fungal antigens using the dot-blot assay. Voriconazole treatment was initiated at the beginning of March 2006, but, curiously, there was an increase in the level of yeast antigens found in the blood, perhaps reflecting the action of this antifungal compound in tissues where infection persisted. For comparison, the same serum samples were tested for the presence of fungal polysaccharides (Ishibashi et al., 2005). The Bio-Rad Platelia Candida AG test gave negative results in our samples (data not shown), whereas positive values were found when the Fungitell kit was employed. This latter test, which measures $\beta-1,3$ glucans, indicated the presence of this polysaccharide in the patient's blood over several years, but with large variations in the different samples assayed. The patient had become negative for this test from January 2006 but tested positive with the dot-blot assay. By comparison, the dotblot assay was much more sensitive than the Fungitell test (Matthews \& Burnie, 1998; Mitsutake et al., 1996; Reboli, 1993), although both assays could be run to confirm the existence of fungal infection. Both assays could be useful for a first diagnosis, but follow-up of the patient should be carried out with the dot-blot test. Serum from a patient may even test negative for both assays, despite some residual infection remaining in some tissues of the body.

Finally, the specificity of the dot-blot assay was analysed employing several rabbit polyclonal antibodies raised 

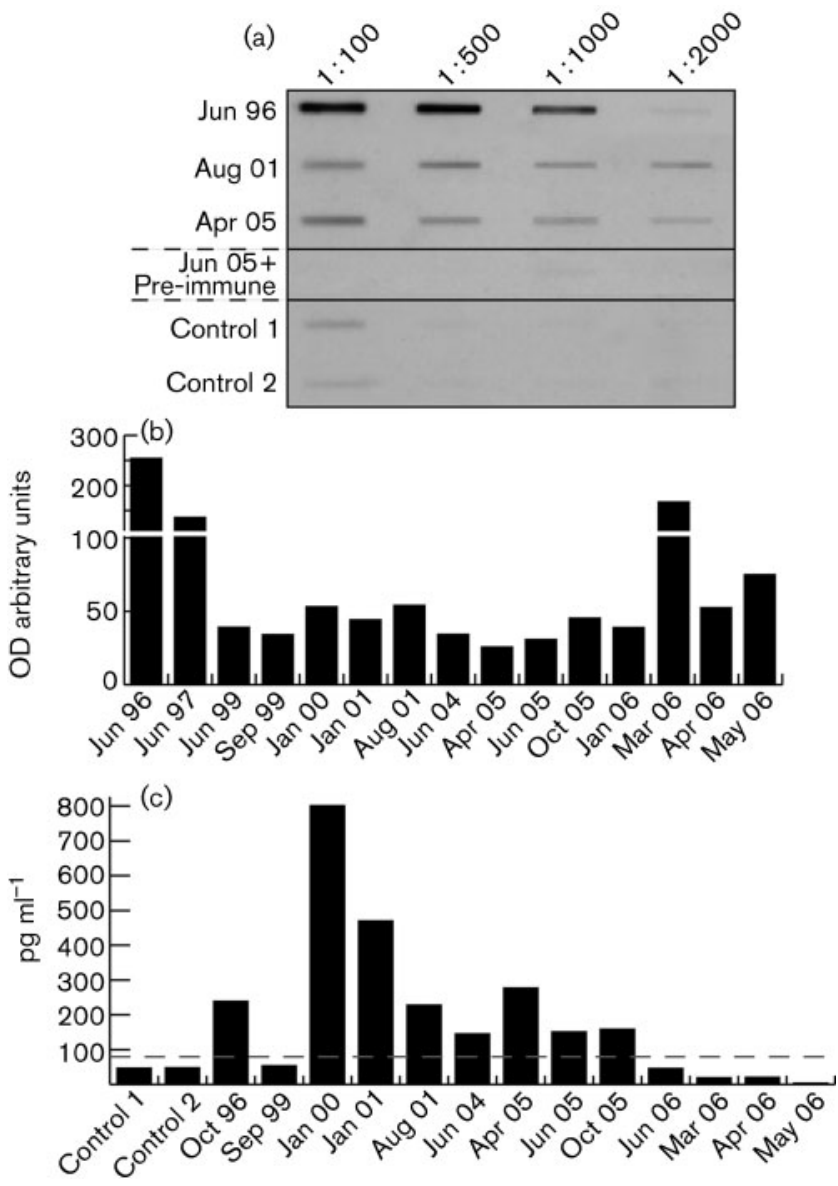

Fig. 5. (a) Dot-blot detection of $C$. famata antigens in patient sera. Different dilutions of sera were blotted onto nitrocellulose membrane and incubated with rabbit antiserum raised against $C$. famata. Rabbit pre-immune serum and sera from two healthy donors (controls 1 and 2) were used as controls. (b) Densitometric values of the $1: 500$ dilution from the dot blot of $C$. famata antigen in different serum samples obtained from the patient between 1996 and 2006. (c) Detection of fungal polysaccharides in different serum samples using a Fungitell kit. The dashed line indicates the minimum level of antigen necessary for the sample to be considered positive. Controls 1 and 2 were sera from healthy donors.

against different yeast species (C. albicans, C. parapsilosis, C. glabrata, R. mucilaginosa and S. cerevisiae). The potency and specificity of these antibodies were estimated using immunofluorescence and Western blot assays against the corresponding yeasts. Specific reactivity of the serum was exhibited against C. famata antibodies, whereas partial cross-reactivity was found with rabbit antibodies raised against other yeasts but not with the anti-S. cerevisiae antibodies (Fig. 6). In conclusion, these findings indicated that patient serum contains antigens that are preferentially recognized by $C$. famata antibodies and that partially crossreact with antibodies against other related yeast species.
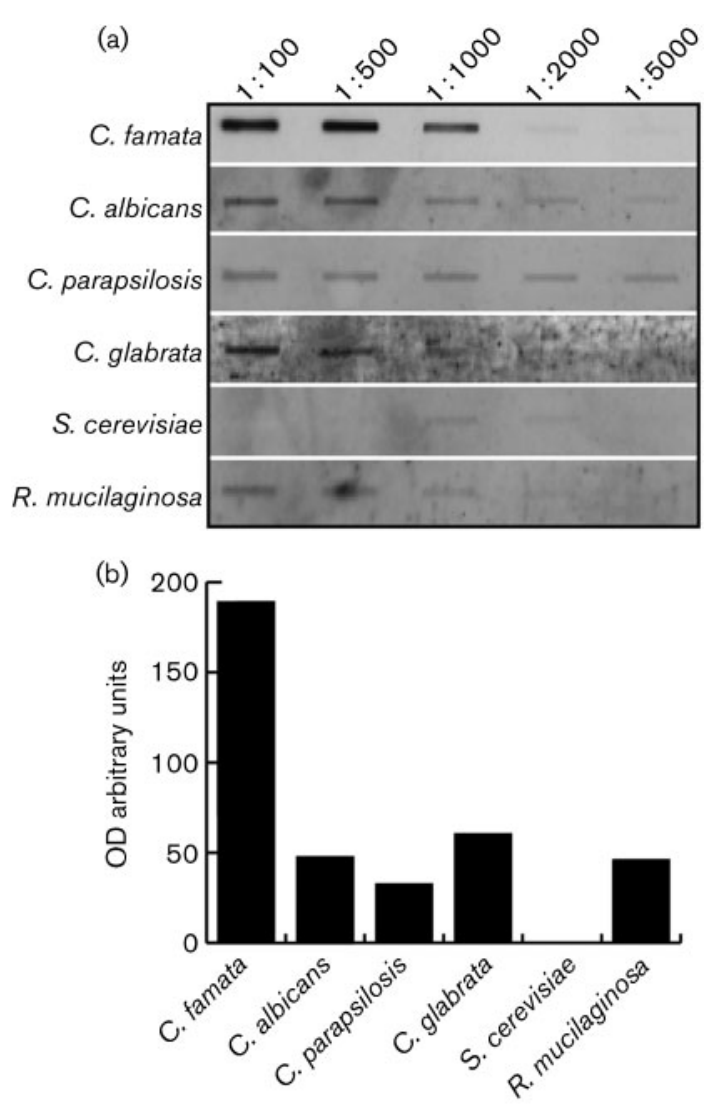

Fig. 6. Dot-blot analysis of the patient serum using rabbit antibodies raised against different yeasts. (a) Dilutions from $1: 200$ to $1: 5000$ of the serum obtained from the patient in June 1996 were blotted and the nitrocellulose membrane was incubated with different antisera raised against the indicated species, obtained as described in Methods. (b) Densitometric values of the 1: 500 dilutions shown in (a).

In this work, we have examined in detail one patient infected with $C$. famata. In order to generalize the findings reported, more patients should be studied. Little is known about the human immune response to disseminated infection by $C$. famata. In principle, this yeast has been classified as non-pathogenic and so does not produce an overt inflammatory reaction. C. famata may use different strategies to evade the immune response, one of them being the production of superoxide dismutase, which interferes with macrophage function (Garcia-Gonzalez \& Ochoa, 1999). Other strategies common to other yeasts may be the production of a mucous environment, as well as precipitation of calcium carbonate at the sites of infection as a result of the drop in $\mathrm{pH}$ associated with fungal metabolic activity. In the patient studied here, the immune response with regard to antibody production was rather weak. The IgM response quickly disappeared after several months of antifungal treatment, even though the infection still remained in the periocular mucosa and probably in the retina and optic nerve. The cellular immune response of 
this patient measured by the presence of specific $\mathrm{T}$ lymphocytes was also low, despite the fact that he was not immunocompromised and was healthy apart from the vision problems. The rather low stimulation of the immune system observed in this patient thus may be one of the reasons for the prolonged infection described. Stimulation of the immune system certainly may help to combat and eventually eradicate this infection (Lopez-Ribot et al., 2004).

From the point of view of diagnosis, we developed and compared different approaches to detect C. famata infection. Although the presence of the antibody response should be assayed, as in other Candida infections, this test is of limited diagnostic value (Quindos et al., 2004). It must be stressed that the presence of viable Candida in blood was rarely detected in our patient. Once again, although haemoculture should be done, the absence of yeast growth does not rule out the possibility of a systemic or disseminated infection (Einsele et al., 1997). The use of PCR is of greater value. Although this technique is very sensitive and we can detect a single genome copy in our assays, fungal genomes may not be circulating in the blood, i.e. the yeast may be located at foci in different tissues without any cells, either dead or alive, entering the bloodstream (Khan \& Mustafa, 2001). Under these conditions, it is possible that the synthesis of polysaccharides may occur or export proteins could reach the blood and these could be detected in the serum (Mitsutake et al., 1996; Pontón, 2006). In this regard, the system developed to analyse C. famata antigens by dot blot using a rabbit antiserum was of special interest. This assay was highly sensitive, as the presence of these antigens could be detected at a $1: 500$ or even a $1: 1000$ dilution. With this test, we could monitor the efficacy of the different antifungal treatments. The amount of protein detected by this method was in the femtomolar range, which is below the limit of detection of Western blotting.

\section{ACKNOWLEDGEMENTS}

The financial support from ONCE (Organización Nacional de Ciegos Españoles) is greatly acknowledged. The Centro de Biología Molecular is financed by an institutional grant from the Fundación Ramón Areces.

\section{REFERENCES}

Al-Hedaithy, S. S. (2003). The yeast species causing fungemia at a university hospital in Riyadh, Saudi Arabia, during a 10-year period. Mycoses 46, 293-298.

Almirante, B., Rodriguez, D., Cuenca-Estrella, M., Almela, M., Sanchez, F., Ayats, J., Alonso-Tarres, C., Rodriguez-Tudela, J. L. \& Pahissa, A. (2006). Epidemiology, risk factors, and prognosis of Candida parapsilosis bloodstream infections: case-control populationbased surveillance study of patients in Barcelona, Spain, from 2002 to 2003. J Clin Microbiol 44, 1681-1685.

Altamura, M., Casale, D., Pepe, M. \& Tafaro, A. (2001). Immune responses to fungal infections and therapeutic implications. Curr Drug Targets Immune Endocr Metabol Disord 1, 189-197.
Andrighetto, C., Psomas, E., Tzanetakis, N., Suzzi, G. \& Lombardi, A. (2000). Randomly amplified polymorphic DNA (RAPD) PCR for the identification of yeasts isolated from dairy products. Lett Appl Microbiol 30, 5-9.

Badauy, C. M., Barbachan, J. J., Rados, P. V., Sant'ana Filho, M. \& Chies, J. A. (2005). Relationship between Candida infection and immune cellular response in inflammatory hyperplasia. Oral Microbiol Immunol 20, 89-92.

Brandt, M. E., Harrison, L. H., Pass, M., Sofair, A. N., Huie, S., Li, R. K., Morrison, C. J., Warnock, D. W. \& Hajjeh, R. A. (2000). Candida dubliniensis fungemia: the first four cases in North America. Emerg Infect Dis 6, 46-49.

Bretagne, S. \& Costa, J. M. (2005). Towards a molecular diagnosis of invasive aspergillosis and disseminated candidosis. FEMS Immunol Med Microbiol 45, 361-368.

Canteros, G. E., Davel, G. O. \& Vivot, W. (1994). Causal agents of onychomycosis. Rev Argent Microbiol 26, 65-71 (in Spanish)

Carrasco, L., Ramos, M., Galisteo, R., Pisa, D., Fresno, M. \& Gonzalez, M. E. (2005). Isolation of Candida famata from a patient with acute zonal occult outer retinopathy. J Clin Microbiol 43, 635-640.

Clemons, K. V., Calich, V. L., Burger, E., Filler, S. G., Grazziutti, M., Murphy, J., Roilides, E., Campa, A., Dias, M. R. \& other authors (2000). Pathogenesis I: interactions of host cells and fungi. Med Mycol 38 (Suppl. 1), 99-111.

Coleman, D. C., Rinaldi, M. G., Haynes, K. A., Rex, J. H., Summerbell, R. C., Anaissie, E. J., Li, A. \& Sullivan, D. J. (1998). Importance of Candida species other than Candida albicans as opportunistic pathogens. Med Mycol 36 (Suppl. 1), 156-165.

d'Ostiani, C. F., Del Sero, G., Bacci, A., Montagnoli, C., Spreca, A., Mencacci, A., Ricciardi-Castagnoli, P. \& Romani, L. (2000). Dendritic cells discriminate between yeasts and hyphae of the fungus Candida albicans. Implications for initiation of T helper cell immunity in vitro and in vivo. J Exp Med 191, 1661-1674.

Einsele, H., Hebart, H., Roller, G., Loffler, J., Rothenhofer, I., Muller, C. A., Bowden, R. A., van Burik, J., Engelhard, D. \& other authors (1997). Detection and identification of fungal pathogens in blood by using molecular probes. J Clin Microbiol 35, 1353-1360.

Ellepola, A. N. \& Morrison, C. J. (2005). Laboratory diagnosis of invasive candidiasis. J Microbiol 43, 65-84.

Fanci, R., Guidi, S., Bonolis, M. \& Bosi, A. (2005). Candida krusei fungemia in an unrelated allogeneic hematopoietic stem cell transplant patient successfully treated with caspofungin. Bone Marrow Transplant 35, 1215-1216.

Fernandez-Arenas, E., Molero, G., Nombela, C., Diez-Orejas, R. \& Gil, C. (2004). Contribution of the antibodies response induced by a low virulent Candida albicans strain in protection against systemic candidiasis. Proteomics 4, 1204-1215.

Garcia-Gonzalez, A. \& Ochoa, J. L. (1999). Anti-inflammatory activity of Debaryomyces hansenii Cu,Zn-SOD. Arch Med Res 30, 69-73.

Gardini, F., Suzzi, G., Lombardi, A., Galgano, F., Crudele, M. A., Andrighetto, C., Schirone, M. \& Tofalo, R. (2001). A survey of yeasts in traditional sausages of southern Italy. FEMS Yeast Res 1, 161-167.

Gil, M. (1997). Conceptos básicos sobre la interacción del sistema inmune y los hongos causales de micosis sistémicas. IATREIA 10, 171-176.

Ishibashi, K., Yoshida, M., Nakabayashi, I., Shinohara, H., Miura, N. N., Adachi, Y. \& Ohno, N. (2005). Role of anti- $\beta$-glucan antibody in host defense against fungi. FEMS Immunol Med Microbiol 44, 99-109.

Khan, Z. U. \& Mustafa, A. S. (2001). Detection of Candida species by polymerase chain reaction (PCR) in blood samples of experimentally 
infected mice and patients with suspected candidemia. Microbiol Res 156, 95-102.

Krcmery, V. \& Barnes, A. J. (2002). Non-albicans Candida spp. causing fungaemia: pathogenicity and antifungal resistance. $J$ Hosp Infect 50, 243-260.

Krcmery, V. \& Kunova, A. (2000). Candida famata fungemia in a cancer patient: case report. J Chemother 12, 189-190.

Li, Y. L., Leaw, S. N., Chen, J. H., Chang, H. C. \& Chang, T. C. (2003). Rapid identification of yeasts commonly found in positive blood cultures by amplification of the internal transcribed spacer regions 1 and 2. Eur J Clin Microbiol Infect Dis 22, 693-696.

Lopez-Ribot, J. L., Casanova, M., Murgui, A. \& Martinez, J. P. (2004). Antibody response to Candida albicans cell wall antigens. FEMS Immunol Med Microbiol 41, 187-196.

Matthews, R. \& Burnie, J. (1998). The epidemiology and pathogenesis of candidiasis: application in prevention and treatment. Bull Inst Pasteur 96, 249-256.

Mencacci, A., Cenci, E., Del Sero, G., d'Ostiani, C. F., Montagnoli, C., Bacci, A., Bistoni, F. \& Romani, L. (1999). Innate and adaptive immunity to Candida albicans: a new view of an old paradigm. Rev Iberoam Micol 16, 4-7.

Mitsutake, K., Miyazaki, T., Tashiro, T., Yamamoto, Y., Kakeya, H., Otsubo, T., Kawamura, S., Hossain, M. A., Noda, T. \& other authors (1996). Enolase antigen, mannan antigen, Cand-Tec antigen, and $\beta$-glucan in patients with candidemia. J Clin Microbiol 34, 1918-1921.

Nishikawa, A., Sugita, T. \& Shinoda, T. (1999). Rapid identification of Debaryomyces hansenii/Candida famata by polymerase chain reaction. Med Mycol 37, 101-104.

Pazos, C., Ponton, J. \& Del Palacio, A. (2005). Contribution of $(1 \rightarrow 3)$ - $\beta$-D-glucan chromogenic assay to diagnosis and therapeutic monitoring of invasive aspergillosis in neutropenic adult patients: a comparison with serial screening for circulating galactomannan. $J$ Clin Microbiol 43, 299-305.

Peres-Bota, D., Rodriguez-Villalobos, H., Dimopoulos, G., Melot, C. \& Vincent, J. L. (2004). Potential risk factors for infection with Candida spp. in critically ill patients. Clin Microbiol Infect 10, 550-555.

Pfaller, M. A. (1996). Nosocomial candidiasis: emerging species, reservoirs, and modes of transmission. Clin Infect Dis 22 (Suppl. 2), S89-S94.

Pfaller, M. A., Diekema, D. J., Messer, S. A., Boyken, L., Hollis, R. J. \& Jones, R. N. (2003). In vitro activities of voriconazole, posaconazole, and four licensed systemic antifungal agents against Candida species infrequently isolated from blood. J Clin Microbiol 41, 78-83.

Pontón, J. (2006). El diagnóstico microbiológico independiente de cultivo en la candidiasis invasora. Importanciae los marcadores fúngicos. Rev Iberoam Micol 23, 20-25.

Prinsloo, B., Weldhagen, G. F. \& Blaine, R. W. (2003). Candida famata central nervous system infection. S Afr Med J 93, 601-602.

Pryce, T. M., Kay, I. D., Palladino, S. \& Heath, C. H. (2003). Real-time automated polymerase chain reaction (PCR) to detect Candida albicans and Aspergillus fumigatus DNA in whole blood from highrisk patients. Diagn Microbiol Infect Dis 47, 487-496.

Quindos, G., Moragues, M. D. \& Ponton, J. (2004). Is there a role for antibody testing in the diagnosis of invasive candidiasis? Rev Iberoam Micol 21, 10-14.
Rao, N. A., Nerenberg, A. V. \& Forster, D. J. (1991). Torulopsis candida (Candida famata) endophthalmitis simulating Propionibacterium acnes syndrome. Arch Ophthalmol 109, 1718-1721.

Reboli, A. C. (1993). Diagnosis of invasive candidiasis by a dot immunobinding assay for Candida antigen detection. J Clin Microbiol 31, 518-523.

Rozell, B., Ljungdahl, P. O. \& Martinez, P. (2006). Host-pathogen interactions and the pathological consequences of acute systemic Candida albicans infections in mice. Curr Drug Targets 7, 483-494.

Ruhnke, M. (2006). Epidemiology of Candida albicans infections and role of non-Candida albicans yeasts. Curr Drug Targets 7, 495-504.

Shoham, S. \& Levitz, S. M. (2005). The immune response to fungal infections. Br J Haematol 129, 569-582.

Simitsopoulou, M. \& Roilides, E. (2005). Evaluation of immunotherapy in invasive candidiasis: antifungal activity and cytokine expression assays. Methods Mol Med 118, 161-179.

Sims, C. R., Ostrosky-Zeichner, L. \& Rex, J. H. (2005). Invasive candidiasis in immunocompromised hospitalized patients. Arch Med Res 36, 660-671.

St-Germain, G. \& Laverdiere, M. (1986). Torulopsis candida, a new opportunistic pathogen. J Clin Microbiol 24, 884-885.

Tortorano, A. M., Kibbler, C., Peman, J., Bernhardt, H., Klingspor, L. \& Grillot, R. (2006). Candidaemia in Europe: epidemiology and resistance. Int J Antimicrob Agents 27, 359-366.

van Deventer, A. J. M., Goessens, W. H. F., van Belkum, H. J. A., van Vliet, H. J. A., van Etten, E. W. M. \& Verbrugh, H. A. (1995). Improved detection of Candida albicans by PCR in blood of neutropenic mice with systemic candidiasis. J Clin Microbiol 33, 625-628.

Veldman, B. A., Verweij, P. E. \& Blijlevens, N. M. (2006). Successful treatment of liposomal amphotericin B refractory Candida glabrata fungaemia in a patient undergoing a stem cell transplantation. Neth $\mathrm{J}$ Med 64, 127-129.

Villar, C. C., Kashleva, H., Mitchell, A. P. \& Dongari-Bagtzoglou, A. (2005). Invasive phenotype of Candida albicans affects the host proinflammatory response to infection. Infect Immun 73, 4588-4595.

Wagner, D., Sander, A., Bertz, H., Finke, J. \& Kern, W. V. (2005). Breakthrough invasive infection due to Debaryomyces hansenii (teleomorph Candida famata) and Scopulariopsis brevicaulis in a stem cell transplant patient receiving liposomal amphotericin B and caspofungin for suspected aspergillosis. Infection 33, 397-400.

Witkin, S. S., Yu, I. R. \& Ledger, W. J. (1983). Inhibition of Candida albicans-induced lymphocyte proliferation by lymphocytes and sera from women with recurrent vaginitis. Am J Obstet Gynecol 147, 809-811.

Wright, R., Basson, M., D’Ari, L. \& Rine, J. (1988). Increased amounts of HMG-CoA reductase induce "Karmellae": a proliferation of stacked membrane pairs surrounding the yeast nucleus. J Cell Biol 107, 101-114.

Yamamoto, Y., Osanai, S., Fujiuchi, S., Yamazaki, K., Nakano, H., Ohsaki, Y. \& Kikuchi, K. (2002). Extrinsic allergic alveolitis induced by the yeast Debaryomyces hansenii. Eur Respir J 20, 1351-1353.

Yang, C. W., Barkham, T. M., Chan, F. Y. \& Wang, Y. (2003). Prevalence of Candida species, including Candida dubliniensis, in Singapore. J Clin Microbiol 41, 472-474.

Yeo, S. F. \& Wong, B. (2002). Current status of nonculture methods for diagnosis of invasive fungal infections. Clin Microbiol Rev 15, $465-484$. 